14. Huggenberger, F., J. Letey, Jr., and W. J. Farmer. 1973. Adsorption and mobility of pesticides in soil. Calif. Agric. 27:8-10.

15. Jury, W. A., R. Grover, W. F. Spencer, and W. J. Farmer. 1980. Modeling vapor losses of soil-incorporated triallate. Soil Sci. Soc. Am. J. 44:445-450.

16. Jury, W. A., W. J. Farmer, and W. F. Spencer. 1984a. Behavior assessment model for trace organics in soil: II. Chemical classification and parameter sensitivity. J. Environ. Qual. 13:567-572 (this issue).

17. Jury, W. A., W. F. Spencer, and W. J. Farmer. 1983. Behavior assessment model for trace organics in soil: I. Model description. J. Environ. Qual. 12:558-563.

18. Jury, W. A., W. F. Spencer, and W. J. Farmer. 1984b. Behavior assessment model for trace organics in soil. III. Application of screening model. J. Environ. Qual. 13:573-579 (this issue).

19. Karickhoff, S. W., D. S. Brown, and T. A. Scott. 1971. Sorption of hydrophobic pollutants on natural sediments and soils. Water Res. 13:241-248.

20. Kearney, P. C., T. J. Sheets, and J. W. Smith. 1964. Volatility of seven $s$-triazines. Weeds 12:83-87.

21. King, P. H., and P. L. McCarty. 1968. A chromatographic model for predicting pesticide migration in soils. Soil Sci. 105: 248-261.

22. Letey, J., and W. J. Farmer. 1973. Movement of pesticides in soil. p. 67-97. In W. D. Guenzi (ed.) Pesticides in soil and water. Soil Science Society of America, Madison, WI.

23. Mayer, R., W. J. Farmer, and J. Letey. 1974. Models for predicting volatilization of soil-applied pesticides. Soil Sci. Soc. Am. Proc. 38:563-568.

24. McCall, P. J., R. L. Swann, D. A. Laskowski, S. M. Unger, S. A. Vrona, and H. J. Dishburger. 1980. Estimation of chemical mobility in soil from liquid chromatographic retention times. Bull. Environ. Contam. Toxicol. 24:190-195.

25. Millington, R. J., and J. M. Quirk. 1961. Permeability of porous solids. Trans. Faraday Soc. 57:1200-1207.
26. Mingelgrin, U., and Z. Gerstl. 1983. Reevaluation of partitioning as a mechanism of nonionic chemical adsorption in soil. J. Environ. Qual. 12:1-11.

27. Rao, P. S. C., and J. M. Davidson. 1980. Estimation of pesticide retention and transformation parameters required in nonpoint source pollution models. p. 23-67. In M. R. Overcash and J. M. Davidson (ed.) Environmental impact of nonpoint source pollution. Ann Arbor Science Publishers, Inc., Ann Arbor, MI.

28. Sallam, A., W. A. Jury, and J. Letey. 1984. Measurement of gas diffusion coefficient under relatively low air-filled porosity. Soil Sci. Soc. Am. J. 48:3-6.

29. Shearer, R. C., J. Letey, W. J. Farmer, and A. Klute. 1973. Lindane diffusion in soil. Soil Sci. Soc. Am. Proc. 37:189-193.

30. Spencer, W. F., and M. M. Cliath. 1973. Pesticide volatilization as related to water loss from soil. J. Environ. Qual. 2:284-289.

31. Spencer, W. F., and M. M. Cliath. 1974. Factors affecting the loss of trifluralin from soils. J. Agric. Food Chem. 22:987-991.

32. Spencer, W. F., M. M. Cliath, and W. J. Farmer. 1969. Vapor density of soil-applied dieldrin as related to soil-water content, temperature, and dieldrin concentration. Soil Sci. Soc. Am. Proc. 33:509-511.

33. Swartzenbach, R. P., and J. Westall. 1981. Transport of nonpolar organic compounds from surface water to groundwater. Laboratory sorption studies. Environ. Sci. Technol. 11:13601367.

34. Weber, J. B., and D. M. Whitacre. 1982. Mobility of herbicides in soil columns under saturated- and unsaturated-flow conditions. Weed Sci. 30:579-584.

35. Willis, G. H., J. F. Parr, S. Smith, and B. R. Carroll. 1972. Volatilization of dieldrin from fallow soil as affected by different soil water regimes. J. Environ. Qual. 1:193-196.

36. Yang, M.-S. 1978. Processes of adsorption, desorption, degradation, volatilization, and movement of $O, O$-Diethyl $O$-p-Nitrophenol phosphorothioate (parathion) in soils. Ph.D. Dissertation. University of California, Davis.

\title{
The Impact of Nitrification on Soil Acidification and Cation Leaching in a Red Alder Ecosystem ${ }^{1}$
}

\author{
H. VAN MIEGROET AND D. W. COLE ${ }^{2}$
}

\begin{abstract}
The objectives of this study were to investigate the impacts of internal nitrification on soil and soil solution acidity and on the rate of nutrient export through $\mathrm{NO}_{3}{ }^{-}$mediated leaching. This was achieved by comparing soil chemical properties and soil solution composition within a naturally $\mathrm{N}$-rich red alder (Alnus rubra Bong.) ecosystem to those of an adjacent Douglas-fir [Pseudotsuga menziesii (Mirbel) Francol forest where soil $\mathbf{N}$ levels were significantly lower and no measurable $\mathrm{HNO}_{3}$ production could be observed. In the red alder system, where $>100 \mathrm{~kg} \mathrm{ha}^{-1} \mathrm{yr}^{-1}$ of $\mathrm{N}$ were added through symbiotic $\mathrm{N}_{2}$ fixation, the net annual $\mathrm{NO}_{3}{ }^{-}$leaching past the $40-\mathrm{cm}$ soil depth amounted to $3460 \mathrm{~mol}$ charges $\mathrm{ha}^{-1}$, and $\mathrm{NO}_{3}^{-}$concentrations in the solutions collected below $40 \mathrm{~cm}$ periodically exceeded drinking water standards of $10 \mathrm{mg} \mathrm{L}^{-1}$. The $\mathrm{H}^{+}$and $\mathrm{NO}_{3}^{-}$release was most pronounced in the forest floor and top $10 \mathrm{~cm}$ of the soil under alder occupancy and caused significant acidification of percolating solutions. Less than $1 \%$ of the total $\mathrm{H}^{+}$input from internal (nitrification) and external (atmospheric) sources leached below the $40-\mathrm{cm}$ depth, which was indicative for the strong buffering capacity of this particular soil. The cation displacement reactions involved in this pH buffering caused a $15 \%$ decline in base saturation and a significant acidification of the upper part of the soil profile. The presence of large amounts of mobile $\mathrm{NO}_{3}{ }^{-}$in solution triggered accelerated cation leaching, causing a selective redistribution of primarily exchangeable $\mathrm{Ca}^{2+}$ from the $\mathrm{A}$ to the B horizon. These field studies lead us to conclude that the rate and the selectivity of $\mathrm{NO}_{3}{ }^{-}$mediated leaching in a red alder system could significantly lower the exchangeable cation pool in the rooting zone or
\end{abstract}

cause nutrient imbalance, if a site is managed for repeated rotations of red alder.

Additional Index Words: forest soil fertility, internal acidification, nitrogen fixation, nitrogen status, $\mathrm{pH}$ buffering, soil base capital.

Van Miegroet, H., and D. W. Cole. 1984. The impact of nitrification on soil acidification and cation leaching in a red alder ecosystem. J. Environ. Qual. 13:586-590.

Red alder (Alnus rubra Bong.) is a pioneer species found extensively in the Pacific Northwest on alluvial flats, riverbanks, disturbed sites, or in recently cleared or disturbed forest areas (Johnson, 1968; Newton et al., 1968). Its early invasion of disturbed forest sites and rapid juvenile growth (Newton et al., 1968) has frequently made this species an unwelcome competitor in high value conifer plantations. Because of the ability of red alder to symbiotically fix atmospheric $\mathrm{N}$ at rates ranging between 50 and $200 \mathrm{~kg} \mathrm{~N} \mathrm{ha}^{-1} \mathrm{yr}^{-1}$ (Binkley,

'Research sponsored jointly by the National Science Foundation's Ecosystem Studies Program (DEB 78-24395) and the Electric Power Research Inst. under contract RP-1813-1 with Martin Marietta Energy Systems Environ. Sci. Div., Oak Ridge National Laboratory, Oak Ridge, TN. Received 14 Nov. 1983.

${ }^{2}$ Research associate and professor of forest soils, respectively, College of Forest Resources, Univ. of Washington, Seattle, WA 98195. 
1981; Cole et al., 1978; DeBell \& Radwan, 1979; Franklin et al., 1968; Zavitkovski \& Newton, 1968), the utilization of red alder has sometimes been proposed as an alternative to $\mathrm{N}$ fertilization of $\mathrm{N}$-deficient conifer forests (Atkinson \& Hamilton, 1978).

Red alder may improve site fertility by increasing organic matter and $\mathrm{N}$ content of the soil (Bormann \& DeBell, 1981; Tarrant, 1961; Tarrant \& Miller, 1963) and yield increases in conifer stands containing red alder have been reported (Binkley, 1983; Miller \& Murray, 1978). Franklin et al. (1968), on the other hand, noted that the presence of red alder in the vegetative cover lowered soil acidity by one $\mathrm{pH}$ unit and caused a significant drop (from 10 to $16 \%$ to 4 to $5 \%$ ) in the base saturation of the A horizons. It thus seems that while improving the soil $\mathrm{N}$ status, red alder may also adversely affect site fertility, particularly in those soils already low in exchangeable bases.

It is the purpose of this paper to investigate the impact of red alder on soil and solution chemistry from a mechanistic point of view. Emphasis is placed on the identification of the major chemical processes and the mechanisms by which changes may occur, rather than on the changes themselves. The importance of the nitrification process in regulating soil and solution $\mathrm{pH}$ and exchangeable cation leaching is examined. The extent and the nature of the changes in soil chemical properties caused by the occupancy of a site with red alder is evaluated from a comparative study between a pure red alder and a pure conifer forest.

\section{POTENTIAL EFFECTS OF NITRIFICATION}

The presence of $\mathrm{N}_{2}$ fixers in the forest cover may result in a gradual buildup of the soil $\mathrm{N}$ capital to levels that will support intensive nitrification, provided no other factors limit microbial activity (Alexander, 1977). This microbial oxidation reaction leads to the formation of $\mathrm{HNO}_{3}$, a strong acid that readily dissociates into one $\mathrm{H}^{+}$and one $\mathrm{NO}_{3}{ }^{-}$. The impact of the nitrification process on soil chemical properties consequently consists of two components: the acidifying effect from the internal $\mathrm{H}^{+}$production, and the acceleration of cation leaching associated with mobile $\mathrm{NO}_{3}{ }^{-}$.

The extent to which percolating solutions are acidified by this nitrification process depends on the rate of such $\mathrm{H}^{+}$release relative to the rate of $\mathrm{H}^{+}$neutralization (or $\mathrm{pH}$ buffering), which frequently involves cation exchange reactions (McFee et al., 1977; Johnson, 1981; Wiklander, 1980b). As the $\mathrm{H}$ ions move through the soil profile, they can gradually displace nutrient bases from the cation exchange complex, thus causing a drop in soil $\mathrm{pH}$ and base saturation and an increase in solution $\mathrm{pH}$. The magnitude of the observed $\mathrm{pH}$ changes will strongly depend on the cation displacing efficiency of produced $\mathrm{H}^{+}$, which in turn varies as a function of $\mathrm{H}^{+}$in solution and bases adsorbed to the soil exchange complex (Wiklander, 1980a; Johnson, 1981). The cations displaced from the exchange complex can either be taken up by plants, by microorganisms, or be carried further down as counter-ions to mobile $\mathrm{NO}_{3}{ }^{-}$(Kinjo \& Pratt, 1971; Wiklander, 1976), which leaches easily through the soil profile when not immobilized biologically
(Reuss, 1977; Vitousek \& Melillo, 1979). Thus, the nitrification process has the potential to acidify the soil and/ or soil solution while removing from the system some of its exchangeable bases. In that $\mathrm{NO}_{3}{ }^{-}$is a highly mobile anion, this process can at the same time increase $\mathrm{NO}_{3}{ }^{-}$ concentrations of groundwater and potentially of streamwater to levels well above the drinking water standards set by the USEPA.

\section{MATERIALS AND METHODS}

\section{Site Description}

The study was conducted at the University of Washington's Thompson Research Center in the Cedar River Watershed, located 56 $\mathrm{km}$ southeast of Seattle, WA in the foothills of the Cascade Mountains. The climate is cool and maritime with cool, dry summers and wet, moderate winters. Mean annual temperature is $9.8^{\circ} \mathrm{C}$ and mean annual precipitation is approximately $130 \mathrm{~cm}$, most of which falls as rain between October and March.

The naturally established stand of red alder abutted against a plantation of Douglas-fir [Pseudotsuga menziesii (Mirbel) Franco]. The soil underlying the sites belongs to the Alderwood series (dystric Entic Durochrepts) and has a gravelly, sandy loam texture (Cole \& Gessel, 1968). The two stands developed almost simultaneously following logging of the original old growth forest approximately $50 \mathrm{yr}$ ago. Thus, parent material, microclimate, stand age, or prior logging history are excluded as significant sources of variability between the forest ecosystems. Observed differences in soil and solution chemistry between the two sites can therefore be attributed to the composition of the vegetative cover and the associated changes in $\mathrm{N}$ status.

\section{Field Measurements}

Precipitation, throughfall, and soil solutions were continuously monitored in 1981 and 1982. Precipitation samples excluding dryfall were collected above the canopy using an automatic sensing wet/dry precipitation collector (Aerochem Metrics, Miami, FL) placed above canopy level in an area close to the study sites. At each study site, throughfall solutions were collected in triplicate by means of open funnels (17.5-cm diam) covered with $1-\mathrm{mm}$ mesh screen and placed on plastic bottles. Soil leachates were monitored by means of tension lysimeters at $10 \mathrm{kPa}(\mathrm{Cole}, 1968)$ installed in triplicate immediately below the forest floor, at the 10 - and $40-\mathrm{cm}$ soil depth. Solution samples were removed from each collection bottle at 28-d intervals and transported to the laboratory.

Immediately upon arrival, each sample was analyzed for $\mathrm{pH}$ by means of a calomel electrode and specific conductance with a conductivity bridge. Concentrations of $\mathrm{Na}^{+}, \mathrm{K}^{+}, \mathrm{Ca}^{2+}$, and $\mathrm{Mg}^{2+}$ were determined with an atomic absorption spectrophotometer, while analyses for $\mathrm{NH}_{4}{ }^{+}, \mathrm{NO}_{3}{ }^{-}, \mathrm{Cl}^{-}, \mathrm{SO}_{4}{ }^{2-}$, and $\mathrm{H}_{2} \mathrm{PO}_{4}{ }^{-}+\mathrm{HPO}_{4}{ }^{2-}$ were performed on a Technicon Auto Analyzer. The $\mathrm{HCO}_{3}{ }^{-}$concentration was calculated from the alkalinity determined by titration to $\mathrm{pH} 4.5$ with $0.01 \mathrm{~mol} \mathrm{~L}^{-1} \mathrm{H}_{2} \mathrm{SO}_{4}$. Average solution $\mathrm{pH}$ values for that particular collection period were derived from weighted average $\mathrm{H}^{+}$concentrations. Annual precipitation, throughfall, and soil drainage flux rates for the various ions were calculated by multiplying weighted mean ion concentration by the appropriate $\mathrm{H}_{2} \mathrm{O}$ volumes. It was observed that during periods of heavy precipitation, excess water was collected by the lysimeter plates. Therefore, during these periods theoretical maximum volumes were used in the total flux calculations mentioned above. These volumes were derived from a hydrological model developed for this area and based on precipitation volume, seasonality, and vegetation type (Knutsen, 1965). Otherwise, collected soil drainage volumes were incorporated into the total ion flux calculation.

In each forest type, soil samples were taken proportionally per horizon from two opposite walls of two soil pits (approximately 1 by $2.5 \mathrm{~m}$ ) dug at about 15 to $40 \mathrm{~m}$ from each other as part of a different study. Each sample was air-dried, sieved (2-mm meshed), and analyzed for its chemical properties using methods described by Johnson et al. (1981). A separate set of four samples was taken at random in each stand for determination of gravel content and bulk density. 
Table 1-Bulk density, gravel content, pH, cation exchange capacity, percent base saturation and total exchangeable base content for the different soil horizons in the Douglas-fir and red alder sites.

\begin{tabular}{|c|c|c|c|c|c|c|c|c|}
\hline \multirow{2}{*}{$\begin{array}{l}\text { Horizon } \\
\text { and } \\
\text { depth }(\mathrm{cm})\end{array}$} & \multirow{2}{*}{$\begin{array}{c}\text { Bulk } \\
\text { density } †\end{array}$} & \multirow{2}{*}{$\begin{array}{c}\text { Gravel } \\
\text { content, } \\
>2 \mathrm{~mm} \dagger\end{array}$} & & & \multirow{2}{*}{$\begin{array}{c}\text { Base } \\
\text { satura- } \\
\text { tion }\end{array}$} & \multicolumn{3}{|c|}{$\begin{array}{c}\text { Total exchangeable } \\
\text { cations }\end{array}$} \\
\hline & & & \multicolumn{2}{|c|}{$\mathrm{I} \dagger \mathrm{CEC} †$} & & $\mathrm{Ca}^{2+}$ & $\mathrm{Mg}^{2+}$ & $\mathrm{K}^{+}$ \\
\hline & $\mathrm{Mg} \mathrm{m}^{-3}$ & $\mathrm{~g} \mathrm{~kg}^{-1}$ & \multicolumn{2}{|c|}{$\underset{\mathrm{kg}^{-1}}{\mathrm{cmol}\left(\mathrm{p}^{+}\right)}$} & $\%$ & \multicolumn{3}{|c|}{$\operatorname{kmol}\left(\mathrm{p}^{*}\right) \mathrm{ha}^{-1}$} \\
\hline \multicolumn{9}{|c|}{ Douglas-fir } \\
\hline A1 (0-7) & 1.03 & 464 & 5.0 & 12.3 & 31 & 10.3 & 1.2 & 1.3 \\
\hline A2 (7-15) & 1.03 & 499 & 5.2 & 9.1 & 16 & 4.5 & 0.7 & 0.8 \\
\hline B21 (15-30) & 1.13 & 499 & 5.1 & 8.1 & 9 & 4.0 & 1.0 & 1.2 \\
\hline B22 (30-45) & 1.34 & 467 & 5.1 & 5.8 & 8 & 2.2 & 0.7 & 1.6 \\
\hline Total & & & & & & 21.0 & 3.6 & 4.9 \\
\hline \multicolumn{9}{|c|}{ Red alder } \\
\hline A1 (0-7) & 0.96 & 620 & 4.6 & 10.1 & 15 & 2.6 & 0.4 & 0.8 \\
\hline A2 (7-15) & 0.96 & 620 & 4.8 & 9.8 & 16 & 3.4 & 0.4 & 0.7 \\
\hline B21 (15-30) & 1.89 & 786 & 5.2 & 7.4 & 19 & 6.9 & 0.6 & 1.3 \\
\hline B22 (30-45) & 1.30 & 595 & 5.2 & 5.7 & 26 & 6.2 & 0.7 & 1.7 \\
\hline Total & & & & & & 19.1 & 2.1 & 4.5 \\
\hline
\end{tabular}

† Johnson et al., 1981.

Results of the soil analysis are summarized in Table 1, and a more detailed description can be found in Johnson et al. (1981).

Statistical significance of differences in mean value between the Douglas-fir and red alder soil and solution properties was determined by means of the Student's $t$-test.

\section{RESULTS AND DISCUSSION}

Research conducted earlier at the study site (Cole et al., 1978) has demonstrated significantly greater annual $\mathrm{N}$ accumulation in the red alder ecosystem as compared with the adjacent Douglas-fir forest. This difference in soil $\mathrm{N}$ content between both forest types was reflected in the chemical composition of percolating solutions. Cation leaching underneath the forest floor and deeper into the soil profile of the red alder ecosystem was strongly dominated by $\mathrm{NO}_{3}{ }^{-}$(Fig. 1). Soil solution $\mathrm{NO}_{3}{ }^{-}$ concentrations in the Douglas-fir ecosystem, by contrast, remained very low $\left(0.01 \mathrm{mmol} \mathrm{NO}_{3}^{-} \mathrm{L}^{-1}\right)$ throughout the observation period. As relatively little $\mathrm{NO}_{3}{ }^{-}$ entered either system from the atmosphere via the throughfall solution (Fig. 1 and Table 2), the $\mathrm{NO}_{3}{ }^{-}$ observed in the red alder ecosystem must thus have been produced internally.

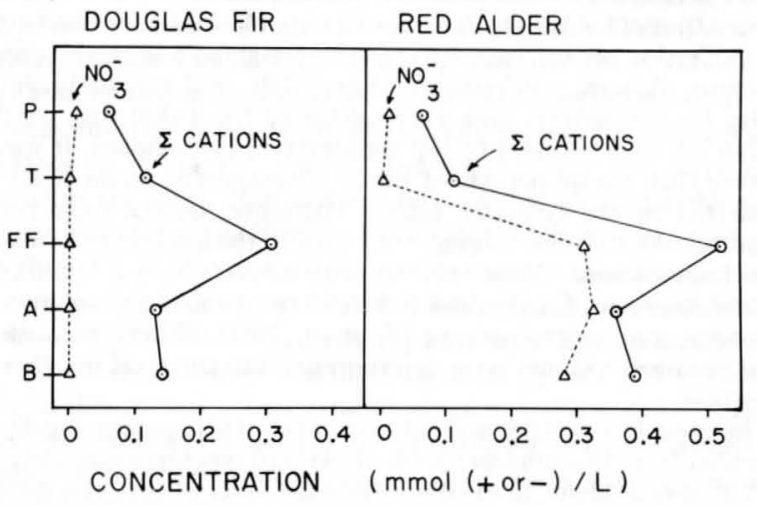

Fig. 1-Weighted average annual $\mathrm{NO}_{3}{ }^{-}$and total cation concentration in precipitation $(P)$, throughfall $(T)$, forest floor $(F F), A$ horizon $(A)$, and $B$ horizon $(B)$ soil solutions in the Douglas-fir and red alder ecosystem.
Table 2-Mean annual anion flux and anion budget for a Douglas-fir and red alder ecosystem.

\begin{tabular}{|c|c|c|c|c|c|}
\hline & $\mathrm{HCO}_{3}{ }^{-}$ & $\mathrm{NO}_{3}^{-}$ & $\mathrm{SO}_{4}{ }^{2-}$ & $\mathrm{Cl}^{-}$ & $\begin{array}{c}\text { Total } \\
\text { negative } \\
\text { charges }\end{array}$ \\
\hline & \multicolumn{5}{|c|}{$-\operatorname{mol}\left(\mathrm{e}^{-}\right) \mathrm{ha}^{-1} \mathrm{yr}^{-1}$} \\
\hline & \multicolumn{3}{|c|}{ Douglas-fir } & & \\
\hline Precipitation & 259 & 195 & 540 & 550 & 1540 \\
\hline Throughfall & 274 & 10 & 705 & 642 & 1630 \\
\hline Forest floor & 297 & 9 & 588 & 395 & 1290 \\
\hline $10 \mathrm{~cm}$ & 538 & 11 & 580 & 400 & 1530 \\
\hline $40 \mathrm{~cm}$ & 678 & 14 & 690 & 476 & 1860 \\
\hline \multirow[t]{2}{*}{ Balance $†$} & -419 & +181 & -150 & +74 & -320 \\
\hline & \multicolumn{4}{|c|}{ Red alder } & \\
\hline Precipitation & 259 & 195 & 540 & 550 & 1540 \\
\hline Throughfall & 515 & 19 & 537 & 673 & 1740 \\
\hline Forest floor & 143 & 2134 & 957 & 721 & 3960 \\
\hline $10 \mathrm{~cm}$ & 143 & 3574 & 504 & 545 & 4770 \\
\hline $40 \mathrm{~cm}$ & 543 & 3642 & 392 & 529 & 5110 \\
\hline Balance $†$ & -284 & -3447 & +148 & +21 & -3570 \\
\hline
\end{tabular}

$\dagger+=$ Net accumulation; $-=$ net loss.

Most of the $\mathrm{NO}_{3}{ }^{-}$addition to the solution in this site took place in the forest floor and the top $10 \mathrm{~cm}$ of the soil profile (Table 2), which generally is the locus of intensive microbial activity (Alexander, 1977). By the time the solution reached the $\mathrm{B}$ horizon, the $\mathrm{NO}_{3}{ }^{-}$load increased by a factor of 20 over the input via precipitation (Table 2), and approximately $50 \mathrm{~kg} \mathrm{ha}^{-1} \mathrm{yr}^{-1}$ of $\mathrm{NO}_{3}^{-}-\mathrm{N}$ leached beyond the $40-\mathrm{cm}$ soil depth in the red alder stand. Particularly during periods of intensive microbial activity (late fall and spring), $\mathrm{NO}_{3}{ }^{-}$concentrations in these solution samples exceeded the $10 \mathrm{mg} \mathrm{L}^{-1}$ drinking water standard established by the USEPA.

The difference between $\mathrm{NO}_{3}{ }^{-}$deposition from the atmosphere and $\mathrm{NO}_{3}{ }^{-}$leaching below $40 \mathrm{~cm}$ provided a minimum indication as to the net annual nitrification rate within the forest ecosystem. It did not account for the $\mathrm{NO}_{3}{ }^{-}$formed, but subsequently reduced during uptake by roots and/or microorganisms. In that case, however, the cycle of $\mathrm{N}$ transformations was complete and no net change in the $\mathrm{H}^{+}$balance of the system would occur (Reuss, 1977). The annual production of $3400 \mathrm{~mol}$ charge of $\mathrm{NO}_{3}{ }^{-} \mathrm{ha}^{-1}$ (Table 2) had to be accompanied by the release of an equivalent amount of $\mathrm{H}^{+}$. This microbial process thus represented an internal (natural) $\mathrm{H}^{+}$source 10 times stronger than the current $\mathrm{H}^{+}$input from the atmosphere (Tables 2 and 3 ). It had basically the same acidifying potential as $150 \mathrm{~cm}$ of annual rainfall with an average $\mathrm{pH}$ of 3.6.

The overall impact of such a strong internal source of $\mathrm{H}^{+}$and mobile $\mathrm{NO}_{3}{ }^{-}$on drainage water composition and soil chemical properties was evaluated from a comparison with a system (i.e., Douglas-fir) where no such net $\mathrm{HNO}_{3}$ release could be observed (Fig. 1 and Table 2). Throughfall, forest floor, and soil solutions collected in the latter ecosystem had significantly higher $\mathrm{pH}$ values $(p=0.001)$ than the incident rain water (Fig. 2). This was in strong contrast with the red alder forest, where $\mathrm{H}^{+}$flux increased considerably underneath the forest floor (Table 3 ) and subsurface solutions were always significantly more acid $(p=0.001)$ than those collected at the same depth in the Douglas-fir site (Fig. 2). Observed differences in solution $\mathrm{pH}$ between the two ecosystems were largest in the $\mathrm{A}$ horizon and decreased 
Table 3-Mean annual $\mathrm{H}^{+}$and cation flux and net nutrient balance for a Douglas-fir and red alder ecosystem.

Total Total positive $\mathrm{H}^{*} \mathrm{NH}_{4}{ }^{*} \mathrm{Na}^{+} \mathrm{K}^{*} \mathrm{Ca}^{2+} \mathrm{Mg}^{2 *}$ cations charges

\begin{tabular}{|c|c|c|c|c|c|c|c|c|}
\hline \multirow[b]{2}{*}{ Precipitation } & 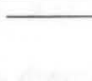 & \multicolumn{3}{|c|}{$\begin{array}{r}\mathrm{mol}\left(\mathrm{p}^{+}\right) \mathrm{ha}^{-1} \mathrm{yr}^{-1} \\
\text { Douglas-fir }\end{array}$} & & $\longrightarrow$ & & \multirow[b]{2}{*}{1330} \\
\hline & 322 & 105 & 582 & 51 & 204 & 72 & 1010 & \\
\hline Throughfall & 146 & 36 & 445 & 405 & 326 & 165 & 1370 & 1520 \\
\hline Forest floor & 45 & 9 & 369 & 170 & 770 & 254 & 1580 & 1620 \\
\hline $10 \mathrm{~cm}$ & 12 & 30 & 383 & 234 & 535 & 208 & 1390 & 1400 \\
\hline $40 \mathrm{~cm}$ & 10 & 52 & 681 & 69 & 507 & 278 & 1590 & 1600 \\
\hline \multirow[t]{2}{*}{ Balance $†$} & +312 & +53 & -99 & -18 & -303 & -206 & -580 & -270 \\
\hline & \multicolumn{6}{|c|}{ Red alder } & & \\
\hline Precipitation & 322 & 105 & 582 & 51 & 204 & 72 & 1010 & 1330 \\
\hline Throughfall & 68 & 39 & 387 & 432 & 297 & 171 & 1320 & 1390 \\
\hline Forest Floor & 173 & 74 & 323 & 802 & 1812 & 594 & 3580 & 3750 \\
\hline $10 \mathrm{~cm}$ & 210 & 29 & 592 & 570 & 2097 & 719 & 3980 & 4190 \\
\hline $40 \mathrm{~cm}$ & 36 & 70 & 1068 & 444 & 2685 & 791 & 5060 & 5100 \\
\hline Balance $†$ & +286 & +35 & -486 & -393 & -2481 & -719 & -4050 & -3770 \\
\hline
\end{tabular}

$++=$ Net accumulation; $-=$ net loss.

again at greater soil depth, although they remained statistically significant (Fig. 2).

The acidification of the solution as it percolated through the forest floor and the top $10 \mathrm{~cm}$ of the red alder soil (Fig. 2) coincided with a pattern of intensive $\mathrm{NO}_{3}{ }^{-}$addition in that particular part of the soil profile (Fig. 1 and Table 2), suggesting that nitrification was the major $\mathrm{H}^{+}$source. The actual amount of $\mathrm{H}^{+}$in solution, however, was considerably lower than could be calculated from the net increase in $\mathrm{NO}_{3}{ }^{-}$flux $(3550 \mathrm{~mol}$ $\mathrm{NO}_{3}{ }^{-} \mathrm{ha}^{-1} \mathrm{yr}^{-1}$ ) between throughfall and upper soil solution (Tables 2 and 3). This discrepancy between theoretical and actual $\mathrm{H}^{+}$load indicated partial buffering of the soil solution against acidification due to the internal formation of $\mathrm{HNO}_{3}$.

A concurrent increase in total cation load of the solution as it percolated across the upper part of the N-rich soil (Table 3) would suggest that a displacement of the exchangeable bases by internally produced $\mathrm{H}^{+}$was the buffer mechanism involved. The significant decline in the percent base saturation of the Al horizon of the red alder soil in comparison to the Douglas-fir A1 (Table 1) further supported this explanation. The increased occupancy of the exchange sites by $\mathrm{H}^{+}$was further reflected in a noticeable $\mathrm{pH}$ drop in the upper layers (0-15 $\mathrm{cm}$ ) of the red alder soil (Table 1). At greater depths no statistically significant differences in soil could be observed between the two ecosystems (Table 1 and Fig. 2).

The nutrients thus displaced from the soil exchange complex could then be transported downward (and potentially out of the rooting zone) when accompanied by an equivalent amount of mobile anions (Nye \& Greenland, 1960). The greater annual anion loss [3250 mol( $\left(\mathrm{e}^{-}\right)$ $\mathrm{ha}^{-1} \mathrm{yr}^{-1}$ ] below the $40-\mathrm{cm}$ soil depth in the red alder as compared with the Douglas-fir ecosystem was almost entirely accounted for by the internal production of mobile $\mathrm{NO}_{3}^{-}$(Table 2). This intensified anion leaching was accompanied by a concurrent increase in cation export $\left[3470 \mathrm{~mol}\left(\mathrm{p}^{+}\right) \mathrm{ha}^{-1} \mathrm{yr}^{-1}\right]$, while the $\mathrm{H}^{+}$balance was almost identical for both ecosystems (Table 3 ). The significance of such cation leaching losses to site fertility and future productivity may be assessed by comparing the magnitude of the net annual cation leaching to the exchangeable cation capital in the soil. In the Douglas-

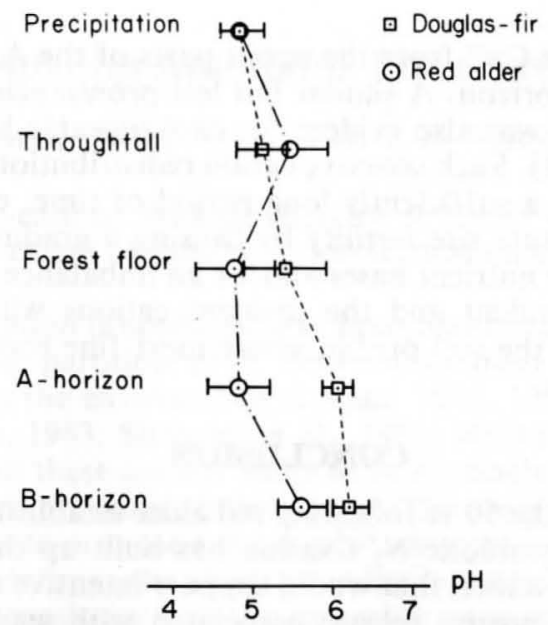

Fig. 2-Average pH of the precipitation, throughfall, forest floor, $\mathrm{A}$ horizon, and $B$ horizon soil solutions in the Douglas-fir and red alder ecosystem in 1981 (mean \pm standard deviation).

fir ecosystem, the net annual leaching losses of $\mathrm{Cu}^{2+}$, $\mathrm{Mg}^{2+}$, and $\mathrm{K}^{+}$combined represented only $1.8 \%$ of the exchangeable pool contained in the top $45 \mathrm{~cm}$ of the soil profile. In the red alder ecosystem, by contrast, as much as $14 \%$ of the exchangeable $\mathrm{Ca}^{2+}, \mathrm{Mg}^{2+}$, and $\mathrm{K}^{+}$was exported annually below the $40-\mathrm{cm}$ depth through $\mathrm{NO}_{3}{ }^{-}$ mediated leaching (Tables 1 and 3 ).

The leaching process worked selectively, causing the largest flux of $\mathrm{Ca}^{2+}$ followed by $\mathrm{Mg}^{2+}$ and $\mathrm{K}^{+}$(Table 3). This dominance of $\mathrm{Ca}^{2+}$ in solution was probably a result of the substantially higher exchangeable $\mathrm{Ca}^{2+}$ levels within the soil profile, as compared with $\mathrm{K}^{+}$and $\mathrm{Mg}^{2+}$ (Table 1). Differences in exchangeable pool sizes, however, could not explain why $\mathbf{M g}^{2+}$ was leaching faster than $\mathrm{K}^{+}$through the soil under alder (Table 3). In fact, the amount of $\mathrm{Mg}^{2+}$ leaching annually below the $40-\mathrm{cm}$ soil depth represented $34 \%$ of the exchangeable $\mathrm{Mg}^{2+}$ capital vs. $9 \%$ for $\mathrm{K}^{+}$. The restricted movement of $\mathrm{K}^{+}$, which was also apparent at greater depth in the Douglas-fir soil (Table 3), could possibly be due to $\mathrm{K}^{+}$ fixation within the lattice structure of the clay fraction. Once fixed, the $\mathrm{K}^{+}$could not as easily be displaced into the soil solution as the other bases adsorbed to the cation exchange complex.

Since exchangeable bases are continually being replenished through weathering, observed cation leaching losses in the Douglas-fir ecosystem probably had little impact on the soil nutrient status. Assuming similar weathering input rates for the two soil types, prolonged alder occupancy and associated $\mathrm{NO}_{3}{ }^{-}$mediated leaching rates could potentially lead to significant decrease in nutrient availability of the site, particularly if processes continue to proceed at rates currently observed. At the end of the first red alder rotation and in spite of high nutrient export rates, no measurable difference in the total exchangeable cation pool could be observed between the top $45 \mathrm{~cm}$ of the soils in the red alder and Douglas-fir sites (Table 1). This would suggest that base input to the soil, either through weathering or organic matter decomposition, is concurrently greater in the red alder site.

Accelerated leaching in the red alder ecosystem, however, has caused a striking redistribution of ex- 
changeable $\mathrm{Ca}^{2+}$ from the upper parts of the A horizon to the B horizon. A similar but less pronounced downward shift was also evident for exchangeable $\mathrm{Mg}^{2+}$ and $\mathrm{K}^{+}$(Table 1). Such selective cation redistribution, if continued for a sufficiently long period of time, could influence future site fertility by causing a gradual depletion of the nutrient bases and/or an imbalance between the monovalent and the divalent cations within that section of the soil profile where most fine root uptake takes place.

\section{CONCLUSION}

During the $50 \mathrm{yr}$. following red alder establishment on the site, symbiotic $\mathrm{N}_{2}$ fixation has built up the soil $\mathrm{N}$ content to a level that would support intensive nitrification. The proton release associated with such $\mathrm{HNO}_{3}$ production and dissociation was found to be a more powerful acidification source than atmospheric $\mathrm{H}^{+}$deposition, even when compared with areas heavily impacted by acid precipitation. However, $<1 \%$ of the total $\mathrm{H}^{+}$input to the soil leached below $40 \mathrm{~cm}$, which served as an indicator for the buffering capacity of this particular soil. It also suggested that in spite of the strong natural $\mathrm{H}^{+}$generation in the red alder site, little danger for groundwater acidification existed.

Water quality, on the other hand, could be adversely affected by the periodically intensive $\mathrm{NO}_{3}{ }^{-}$production. As biological $\mathrm{NO}_{3}{ }^{-}$immobilization remained typically low in the $\mathrm{N}$-rich site, $\mathrm{NO}_{3}{ }^{-}$levels in the percolating solutions often exceeded the USEPA standard of $10 \mathrm{mg}$ $\mathrm{L}^{-1}$. This may become of importance in those areas where $\mathrm{N}_{2}$-fixing species are dominant in watersheds designated for drinking water.

Finally, the production of $\mathrm{HNO}_{3}$ triggered selective displacement and accelerated leaching of the exchangeable cations. The decrease in base saturation has so far remained limited to the upper parts of the soil profile. If areas are dedicated to repeated rotations of red alder, such selective downward movement of exchangeable ions could cause a decline in forest site fertility or nutrient imbalances.

\section{REFERENCES}

1. Alexander, M. 1977. Introduction to soil microbiology. 2nd ed. John Wiley \& Sons, New York.

2. Atkinson, W. A., and W. I. Hamilton. 1978. The value of red alder as a source of nitrogen in Douglas-fir/Alder mixed stands. p. 337-351. In D. G. Briggs et al. (ed.) Utilization and management of alder. USDA Forest Service Gen. Tech. Rep. PNW-70. U.S. Government Printing Office, Washington, DC.

3. Binkley, D. 1981. Nodule biomass and acetylene reduction rates of red alder and Sitka alder on Vancouver Island, B.C. Can. J. For. Res. 11:281-286.

4. Binkley, D. 1983. Ecosystem production in Douglas-fir plantations: interaction of red alder and site fertility. For. Ecol. Manage. 5:215-227.

5. Bormann, B. T., and D. S. DeBell. 1981. Nitrogen content and other soil properties related to age of red alder stands. Soil Sci. Soc. Am. J. 45:428-432.

6. Cole, D. W. 1968. A system for measuring conductivity, acidity and rate flow in a forest soil. Water Resour. Res. 4:1127-1136.

7. Cole, D. W., and S. P. Gessel. 1968. Cedar River research-a program for studying pathways, rates and processes of elemental cycling in a forest ecosystem. Institute of Forest Products, Uni- versity of Washington, College of Forest Resources Contribution 4. University of Washington, Seattle.

8. Cole, D. W., S. P. Gessel, and J. Turner. 1978. Comparative mineral cycling in red alder and Douglas-fir. p. 327-336. In D. G. Briggs et al. (ed.) Utilization and management of alder. USDA Forest Service Gen. Tech. Rep. PNW-70. U.S. Government Printing Office, Washington, DC.

9. DeBell, D. S., and M. A. Radwan. 1979. Growth and nitrogen relations of coppiced black cottonwood and red alder in pure and mixed plantings. Bot. Gaz. (Chicago) 140:5102-5107. (Supplement.)

10. Franklin, J. F., C. T. Dyrness, D. G. Moore, and R. F. Tarrant. 1968. Chemical soil properties under coastal Oregon stands of alder and conifers. p. 157-172. In J. M. Trappe et al. (ed.) Biology of alder. USDA Pacific Northwest Forest Range Exp. Stn., Portland, OR.

11. Johnson, D. W. 1981. Effects of acid precipitation on elemental transport from terrestrial to aquatic ecosystems. p. 539-545. In R. A. Fozzolare and C. B. Smith (ed.) Beyond the energy crisisopportunity and challenge. Pergamon Press, Oxford.

12. Johnson, D. W., D. W. Cole, F. W. Horng, H. Van Miegroet, and D. E. Todd. 1981. Chemical characteristics of two forested Ultisols and two forested Inceptisols relevant to anion production and mobility. Oak Ridge National Laboratory, Environ. Science Division Pub. 1670. Oak Ridge National Laboratory, Oak Ridge, TN.

13. Johnson, F. D. 1968. Taxonomy and distribution of northwestern alders. p. 9-22. In J. M. Trappe et al. (ed.) Biology of alder. USDA Pacific Northwest Forest Range Exp. Stn., Portland, OR.

14. Kinjo, T., and P. F. Pratt. 1971. Nitrate adsorption: II. In competition with chloride, sulfate and phosphate. Soil Sci. Soc. Am. Proc. 35:725-728.

15. Knutsen, S. K. 1965. Hydrolic processes in thirty and thirty-five year old stands of Douglas-fir and alder in western WashingtonM.S. Thesis. University of Washington, Seattle.

16. McFee, W. W., J. M. Kelly, and R. H. Beck. 1977. Acid precipitation effects on soil $\mathrm{pH}$ and base saturation of exchange sites. Water Air Soil Pollut. 7:401-408.

17. Miller, R. E., and M. D. Murray. 1978. The effects of red alder on growth of Douglas-fir. p. 283-306. In D. G. Briggs et al. (ed.) Utilization and management of alder. USDA Forest Service Gen. Tech. Rep. PNW-70. U.S. Government Printing Office, Washington, DC.

18. Newton, M., B. A. el-Hassan, and J. Zavitkovski. 1968. Role of red alder in western Oregon forest succession. p. 73-84. In J. M. Trappe et al. (ed.) Biology of alder. Pacific Northwest Forest and Range Exp. Stn., Portland, OR.

19. Nye, P. H., and D. J. Greenland. 1960. The soil under shifting cultivation. Commonwealth Bureau of Soils Tech. Comm. 51. Commonwealth Agricultural Bureau, Farnham Royal, Bucks.

20. Reuss, J. O. 1977. Chemical and biological relationships relevant to the effect of acid rainfall on the soil-plant system. Water Air Soil Pollut. 7:461-478.

21. Tarrant, R. F. 1961. Stand development and soil fertility in a Douglas-fir-red alder plantation. For. Sci. 7:238-246.

22. Tarrant, R. F., and R. E. Miller. 1963. Accumulation of organic matter and soil nitrogen beneath a plantation of red alder and Douglas-fir. Soil Sci. Soc. Am. Proc. 27:231-234.

23. Vitousek, P. M., and J. M. Melillo. 1979. Nitrate losses from disturbed forests: patterns and mechanisms. For. Sci. 25:605-619.

24. Wiklander, L. 1976. The influence of anions on adsorption and leaching of cations in soils. Grundfoerbaettring 26:125-135.

25. Wiklander, L. 1980a. Interaction between cations and anions influencing adsorption and leaching. p. 239-254. In C. T. Hutchinson and M. Havas (ed.) Effects of acid precipitation on terrestrial ecosystems. Plenum Press, New York and London.

26. Wiklander, L. 1980b. The sensitivity of soils to acid precipitation. p. 553-567. In C. T. Hutchinson and M. Havas (ed.) Effects of acid precipitation on terrestrial ecosystems. Plenum Press, New York and London.

27. Zavitkovski, J., and M. Newton. 1968. Effect of organic matter and combined nitrogen on nodulation and nitrogen fixation in red alder. p. 209-221. In J. M. Trappe et al. (ed.) Biology of alder. USDA Pacific Northwest Forest Range Exp. Stn., Portland, $O R$. 